\title{
Effect of Row Spacing and Cultivar on the Growth and Seed Yield of Soybean (Glycine max [L.] Merrill) in Kharif-II Season
}

\author{
M. M. Rahman ${ }^{1 *}$, M. M. Rahman ${ }^{2}$ and M. M. Hossain ${ }^{1}$ \\ ${ }^{1}$ Department of Agronomy, Bangladesh Agricultural University, Mymensingh \\ ${ }^{2}$ Willes Little Flower School and College, Dhaka, Bangladesh \\ *Corresponding author and Email: rahmanag63@yahoo.com
}

Received: 2 September $2012 \quad$ Accepted: 18 May 2013

\begin{abstract}
An experiment was conducted at the Agronomy Field Laboratory of Bangladesh Agricultural University, Mymensingh during Kharif-II season 2005 to investigate the effect of row spacing and cultivars on the growth and yield of soybean. Three soybean cultivars: (1) Bangladesh Soybean -4 (G2), (2) BARI soybean -5 (BS-5) and (3) Shohag (PB-1) and four row spacings, (1) $20 \mathrm{~cm}$, (2) $30 \mathrm{~cm}$, (3) $40 \mathrm{~cm}$ and (4) $50 \mathrm{~cm}$ were used in the experiment in a split-plot design with row spacing in the main plot and cultivars in the sub-plot. Seeds were sown on 26 July 2005 at specified rows maintaining $5 \mathrm{~cm}$ plant to plant distance. The highest seed yield was obtained from $20 \mathrm{~cm}$ spacing and yield decreased with increased spacing irrespective of cultivars. Among cultivars the highest yield was given by cultivar BS-5 which was followed by PB-1. It was concluded that the soybean cultivars BS-5 and PB-1 could be selected for sowing in Kharif-II season and should be planted at $20 \mathrm{~cm}$ apart rows for achieving higher yield.
\end{abstract}

Keywords: Soybean, cultivar, row spacing, growth, seed yield, kharif-II season

\section{Introduction}

Soybean (Glycine max [L.] Merrill) is the world's most important grain legume crop in terms of total production and international trade. Despite suitable climatic and edaphic conditions, the yield of soybean is very low in Bangladesh. The lower yield at farmer's level is attributed to the poor agronomic management practices and also due to use of low quality seed (Rahman and Islam, 2006). Planting of low quality seeds results in poor seedling emergence and nonuniform plant establishment. Moreover, unavailability of quality seeds is also a cause of limited adoption of the crop.

Soybean is mainly cultivated in rabi season. Unavailability of quality seeds for sowing in rabi season is a major problem in soybean cultivation. Soybean seed losses viability in storage and thus, farmers cannot store seed for their own. They have to use seeds harvested from kharif-II crops. The planting geometry and plant population have not yet been established for kharif-II seed crop. Planting density is an important determinant of seed yield and it plays an important role in modulating the environmental factors related to growth and development of the crop. Planting soybean in rows ensures easy intercultural operations and helps to attain in higher yield. The row spacing recommended for soybean in kharif-II season is $40 \mathrm{~cm}$ (BARI, 2005). However, the relevant research finding in this line for different cultivars is highly scarce. The effect of different row spacing on yield performance of soybean cultivars might help 
determining variety specific row spacing to obtain high yield. Considering these views, the present experiment was undertaken to determine the response of several soybean cultivars grown under varying row spacings.

\section{Materials and Methods}

The experiment was conducted in Kharif-II season during July to November 2005 at the Agronomy Field Laboratory of Bangladesh Agricultural University, Mymensingh. The experiment comprised four row spacings viz. 20, 30,40 and $50 \mathrm{~cm}$ and three cultivars namely, Bangladesh Soybean-4 (G-2), BARI soybean -5 (BS-5) and Shohag (PB-1). The trial was conducted in a split-plot design with row spacings in the main plots and cultivars in the sub-plots. The treatments were replicated three times. The unit plot size was $4 \mathrm{~m} \times 3 \mathrm{~m}$.

The seeds of each variety were inoculated with Rizhobium inoculum and then were sown on 26 July 2005 in rows following treatments. Three manual weedings were done at 21, 35 and 45 days after sowing (DAS). During first and second weeding, thinning was done to maintain a plant to plant spacing of $5 \mathrm{~cm}$. No irrigation was given because heavy rainfall occurred during the whole period of the cropping season. The crop was infested by hairy caterpillar at vegetative, flowering and seed filling stages, which were successfully controlled by application of Dimethion 40 EC @ $1.5 \mathrm{~L} \mathrm{ha}^{-1}$ immediately after infestations. No disease incidence occurred in the crop field.

The crop was harvested from central $6 \mathrm{~m}^{2}(2.4 \mathrm{~m}$ $\times 2.5 \mathrm{~m}$ ) area of each plot at full maturity (when about $80 \%$ pods turned into brown) on 27 October for cultivar G-2 and 13 November for cultivars BS-5 and PB-1. The post harvest processing such as threshing, cleaning and drying were done properly. Prior to harvesting, 10 randomly selected sample plants were uprooted and data on different growth characters and yield components were recorded. Crop growth rate, leaf area index and leaf area duration were recorded by destructive sampling of plants from $0.20 \mathrm{~m}^{-2}$ area at 15 day intervals starting from 30 days after sowing following Gardner et al. (1985). Dry matters of plant samples were also recorded at R5 stage (beginning pod stage) after drying in oven at 80 ${ }^{\circ} \mathrm{C}$ for 72 hours. The collected data were analysed following ANOVA and mean comparison was done by DMRT with the help of MSTAT-C.

\section{Results and Discussion}

\section{Growth attributes}

Leaf area index (LAI), leaf area duration (LAD), total dry matter (TDM) and crop growth rate were varied significantly due to row spacing, cultivars and their interactions. LAI, LAD and TDM were the highest when crops were grown at $20 \mathrm{~cm}$ row spacing (Table 1). The highest values of LAI, LAD, TDM and CGR were 2.14, 96.05 days, $381.91 \mathrm{~g} \mathrm{~m}^{-2}$ and $6.65 \mathrm{~g} \mathrm{~m}^{-2} \mathrm{~d}^{-1}$ respectively at $20 \mathrm{~cm}$ row spacing which decreased with increased row spacing. The lowest values were 1.16, 45.41days, $257.18 \mathrm{~g} \mathrm{~m}^{-2}$ and $3.39 \mathrm{~g} \mathrm{~m}^{-2} \mathrm{~d}^{-1}$, respectively at $50 \mathrm{~cm}$ row spacing (Table 1). These growth parameters were the highest for cultivar BS-5 and the lowest for G-2. The interaction of row spacing to cultivar showed the highest values for LAI, LAD, TDM and CGR for cultivar BS-5 at $20 \mathrm{~cm}$ row spacing which were 2.64, 128.41 days, $479.35 \mathrm{~g} \mathrm{~m}^{-2}$ and $8.41 \mathrm{~g} \mathrm{~m}^{-2} \mathrm{~d}^{-1}$, respectively and the lowest values were for cultivar G-2 at $50 \mathrm{~cm}$ row spacing (Table 1). The result showed that narrowest rows attributed to the highest growth of the crop because of high plant density while widest rows gave the lowest because of low plant density. The results of the present study are in agreement with those reported by Rahman et al. (2005) who found that LAI, LAD, CGR and TDM production increased in soybean with increases in densities for all the cultivars. 
Table 1. Effect of row spacing and cultivar on leaf area index (LAI), leaf area duration (LAD), total dry matter (TDM) at R5 stage and crop growth rate (CGR) of soybean in Kharif-II season

\begin{tabular}{|c|c|c|c|c|}
\hline Treatments & LAI & LAD (days) & TDM $\left(\mathrm{g} \mathrm{m}^{-2}\right)$ & CGR $\left(\mathrm{g} \mathrm{m}^{-2} \mathrm{~d}^{-1}\right)$ \\
\hline \multicolumn{5}{|l|}{ Row spacing $(\mathrm{cm})$} \\
\hline 20 & $2.14 \mathrm{a}$ & $96.05 \mathrm{a}$ & $380.91 \mathrm{a}$ & $6.65 a$ \\
\hline 30 & $1.71 \mathrm{~b}$ & $69.51 b$ & $323.32 b$ & $4.82 b$ \\
\hline 40 & $1.37 \mathrm{bc}$ & $55.33 \mathrm{c}$ & $294.52 b$ & $4.47 b$ \\
\hline 50 & $1.16 \mathrm{c}$ & $45.41 \mathrm{~d}$ & $257.18 \mathrm{c}$ & $3.39 \mathrm{c}$ \\
\hline $\mathrm{CV}(\%)$ & 12.86 & 9.93 & 9.35 & 7.16 \\
\hline SE & 0.0093 & 9.7119 & 191.52 & 0.0266 \\
\hline \multicolumn{5}{|l|}{ Cultivar } \\
\hline G-2 & $1.03 \mathrm{c}$ & $37.42 \mathrm{c}$ & $204.72 c$ & $3.66 \mathrm{c}$ \\
\hline BS-5 & $2.09 \mathrm{a}$ & $90.78 \mathrm{a}$ & $395.65 a$ & $5.85 \mathrm{a}$ \\
\hline PB-1 & $1.66 \mathrm{~b}$ & $71.52 b$ & $341.58 b$ & $4.99 \mathrm{~b}$ \\
\hline $\mathrm{CV}(\%)$ & 5.51 & 8.64 & 7.11 & 13.37 \\
\hline $\mathrm{SE}( \pm)$ & 0.0013 & 5.5141 & 83.0617 & 0.0696 \\
\hline \multicolumn{5}{|c|}{ Cultivar $\quad \times$ Row spacing $(\mathrm{cm})$} \\
\hline 20 & $1.53 \mathrm{~d}$ & $55.59 \mathrm{~d}$ & $233.29 \mathrm{e}$ & $4.72 \mathrm{~cd}$ \\
\hline G-2 & $1.16 \mathrm{e}$ & $39.54 \mathrm{e}$ & $212.08 \mathrm{ef}$ & $3.68 \mathrm{de}$ \\
\hline 40 & $0.79 f$ & $29.07 \mathrm{f}$ & 194.13ef & $3.49 \mathrm{de}$ \\
\hline 50 & $0.63 \mathrm{~g}$ & $25.47 f$ & $178.36 f$ & $2.73 \mathrm{e}$ \\
\hline 20 & $2.64 \mathrm{a}$ & $128.41 \mathrm{a}$ & $479.35 \mathrm{a}$ & $8.41 \mathrm{a}$ \\
\hline BS-5 & $2.24 b$ & $94.47 b$ & $440.15 b$ & $6.59 b$ \\
\hline 40 & $1.74 \mathrm{c}$ & $72.51 \mathrm{c}$ & $350.42 \mathrm{c}$ & $4.61 \mathrm{~cd}$ \\
\hline 50 & $1.77 \mathrm{c}$ & $67.73 c$ & $312.69 \mathrm{~cd}$ & $3.79 \mathrm{de}$ \\
\hline 20 & $2.25 b$ & $104.13 b$ & $430.10 \mathrm{~b}$ & $6.83 b$ \\
\hline PB-1 & $1.73 \mathrm{c}$ & $74.51 \mathrm{c}$ & $317.74 \mathrm{~cd}$ & $4.19 \mathrm{~cd}$ \\
\hline 40 & $1.57 \mathrm{~d}$ & $64.43 \mathrm{~cd}$ & $338.00 f$ & $5.32 \mathrm{c}$ \\
\hline 50 & $1.08 \mathrm{e}$ & $43.02 \mathrm{e}$ & $280.50 \mathrm{~d}$ & $3.65 \mathrm{de}$ \\
\hline $\mathrm{CV}(\%)$ & 5.51 & 8.64 & 7.11 & 13.37 \\
\hline $\mathrm{SE}( \pm)$ & 0.0051 & 22.0565 & 332.07 & 0.2784 \\
\hline
\end{tabular}

Figures having similar letter (s) do not differ significantly at 5\% level as per DMRT

\section{Yield and yield attributes}

Seed yield was significantly influenced by row spacing, cultivar and their interaction (Table 2). The highest seed yield of $133.75 \mathrm{~g} \mathrm{~m}^{-2}$ was produced at $20 \mathrm{~cm}$ rows, while the lowest $\left(105.33 \mathrm{~g} \mathrm{~m}^{-2}\right)$ was found at $50 \mathrm{~cm}$ rows. The result showed that seed yield decreased with increase in row spacing. The cultivar BS-5 gave the highest seed yield $\left(151.24 \mathrm{~g} \mathrm{~m}^{-2}\right)$. The highest seed yield $\left(166.57 \mathrm{~g} \mathrm{~m}^{-2}\right)$ was produced by the cultivar BS-5 at $20 \mathrm{~cm}$ rows while the lowest seed yield $\left(62.40 \mathrm{~g} \mathrm{~m}^{-2}\right)$ was found in cultivar G-2 at $50 \mathrm{~cm}$ rows. In all the three cultivars, seed yield decreased with increase in row spacing (Table 3). Stover yield, total dry matter and harvest index were influenced significantly by row spacing, cultivar and interactions.

The crop sown at $20 \mathrm{~cm}$ rows produced the highest stover yield $\left(179.58 \mathrm{~g} \mathrm{~m}^{-2}\right)$ while the 50 
$\mathrm{cm}$ rows produced the lowest $(118.40 \mathrm{~g})$. Cultivar BS-5 produced the highest stover yield $\left(169.23 \mathrm{~g} \mathrm{~m}^{-2}\right)$ and cultivar G-2 produced the lowest $\left(104.64 \mathrm{~g} \mathrm{~m}^{-2}\right)$. The highest stover yield $\left(233.75 \mathrm{~g} \mathrm{~m}^{-2}\right)$ was produced by cultivar BS-5 at $20 \mathrm{~cm}$ rows, but the lowest $\left(94.80 \mathrm{~g} \mathrm{~m}^{-2}\right)$ was produced by cultivar G-2 at $50 \mathrm{~cm}$ rows. Stover yield decreased with increase in row spacing in all the three cultivars (Table 3). The highest TDM (313.33 $\mathrm{g} \mathrm{m}^{-2}$ ) was produced at $20 \mathrm{~cm}$ rows but the lowest $\left(223.73 \mathrm{~g} \mathrm{~m}^{-2}\right)$ was at $50 \mathrm{~cm}$ rows. The cultivar BS-5 produced the highest TDM (320.46 $\mathrm{g} \mathrm{m}^{-2}$ ) while the lowest was found with G-2 $\left(175.39 \mathrm{~g} \mathrm{~m}^{-2}\right)$. The interaction showed that the highest $\left(400.32 \mathrm{~g} \mathrm{~m}^{-2}\right)$ dry matter was attained in cultivar BS-5 at $20 \mathrm{~cm}$ rows while the lowest $\left(157.20 \mathrm{~g} \mathrm{~m}^{-2}\right)$ was obtained in cultivar G2 at $50 \mathrm{~cm}$ rows (Table 3 ). The highest harvest index $(46.34 \%)$ was at $40 \mathrm{~cm}$ row spacing and values were similar to that at 30 and $50 \mathrm{~cm}$ row spacing (Table 2). The lowest value $(42.51 \%)$ was observed at $20 \mathrm{~cm}$ row spacing. The highest $(47.72 \%)$ harvest index was found in cultivar BS-5 and the lowest in cultivar G-2. Cultivar and row spacing interaction showed that cultivar PB1 sown at $40 \mathrm{~cm}$ rows resulted in the highest harvest index (50.92\%), while the lowest $(38.57 \%)$ was found in cultivar G-2 at $40 \mathrm{~cm}$ rows (Table 3).

Plant height, number of branches plant ${ }^{-1}$, number of fertile and non-fertile pods plant ${ }^{-1}$, number of seeds pod $^{-1}$, and number of seeds plant ${ }^{-1}$ varied significantly with row spacing (Table 2). The tallest plant $(43.74 \mathrm{~cm})$ was found at $20 \mathrm{~cm}$ row spacing while the highest number of branches (2.51) and pods plant ${ }^{-1}$ (19.86) were found at 50 $\mathrm{cm}$ row spacing. The result showed that plant height increased with decreased row spacing but other yield related attributes in individual plants were reduced with increase of row spacing (Table 2). The interaction of cultivar and plant spacing was significant for number of fertile pods plant ${ }^{-1}$, non-fertile pods plant ${ }^{-1}$ and number of seeds plant ${ }^{-1}$ (Table 3) while plant height, number of nodes plant $^{-1}$, number of branches plant $^{-1}$, number of seed pod $^{-1}$ and weight of 100 seed remained unaffected. The result indicated that seed yield of all the soybean varieties increased with decrease of row spacing and the highest was attained at the lowest row spacing of $20 \mathrm{~cm}$.

The present study showed that plant height increased in soybean with decrease of row spacing. The plant density at row spacing of 20 $\mathrm{cm}$ was 100 plants $\mathrm{m}^{-2}$ while that at $40 \mathrm{~cm}$ was only 50 plants $\mathrm{m}^{-2}$. Therefore, the increase in plant height at closer spacing might have been caused due to increased plant population density. The higher population density caused mutual shading in plants that contributed to stem elongation and ultimately plant height increased (Pendersen and Lauer, 2003; Rahman et al., 2004).

The highest seed yield in the lowest spacing could have been achieved by early canopy closure in the narrowest rows that facilitated high TDM production. The leaf area development with closer spacing contributed to high TDM production due to higher solar radiation interception that contributed to higher yield production (Ball et al., 2000). Rahman et al. (2011) also reported the highest seed yield of soybean in kharif-II season at a population density of 80-100 plants $\mathrm{m}^{-2}$ which commensurate the result of the present study. The recommended row spacing for soybean is 40 $\mathrm{cm}$ in kharif $-I I$ season, which is equivalent to a plant population density of 50 plants $\mathrm{m}^{-2}$ (BARI, 2005). The present study, therefore, indicated that the higher seed yield of soybean could be achieved in kharif-II season by planting the crop at a narrower spacing. Similar result was found by Rahman and Hanif (2006) who reported that soybean cv. Shohag gave the highest yield at 15 $\mathrm{cm}$ row spacing in rabi season. Therefore, a row spacing of $20 \mathrm{~cm}$ could be used for these three soybean varieties in kharif-II season to obtain high yield. 
Table 2. Effect of row spacing and cultivar on growth, yield attributes and yield of soybean in Kharif-II season

\begin{tabular}{|c|c|c|c|c|c|c|c|c|c|c|c|c|}
\hline Treatments & $\begin{array}{l}\text { Plant } \\
\text { height } \\
(\mathrm{cm})\end{array}$ & $\begin{array}{l}\text { Nodes } \\
\text { plant }^{-1} \\
\text { (no.) }\end{array}$ & $\begin{array}{l}\text { Branches } \\
\text { plant }^{-1} \\
\text { (no.) }\end{array}$ & $\begin{array}{l}\text { Fertile pods } \\
\text { plant }^{-1} \\
\text { (no.) }\end{array}$ & $\begin{array}{l}\text { Non fertile } \\
\text { pods plant } \\
\text { (no.) }\end{array}$ & $\begin{array}{l}\text { Seeds } \\
\text { pod }^{-1} \\
\text { (no.) }\end{array}$ & $\begin{array}{l}\text { Seed } \\
\text { plant }^{-1} \\
\text { (no.) }\end{array}$ & $\begin{array}{l}\text { Weight of } \\
100 \text { seeds } \\
\text { (g) }\end{array}$ & $\begin{array}{l}\text { Seed } \\
\text { yield ( } \mathrm{g} \\
\left.\mathrm{m}^{-2}\right)\end{array}$ & $\begin{array}{l}\text { Stover } \\
\text { yield } \\
\left(\mathrm{g} \mathrm{m}^{-2}\right)\end{array}$ & $\begin{array}{l}\text { Total dry } \\
\text { mater }(\mathrm{g} \\
\left.\mathrm{m}^{-2}\right)\end{array}$ & $\begin{array}{l}\text { Harvest } \\
\text { index }(\%)\end{array}$ \\
\hline \multicolumn{13}{|c|}{ Row spacing $(\mathrm{cm})$} \\
\hline 20 & $43.74 a$ & 12.63 & $2.03 \mathrm{~b}$ & $15.23 \mathrm{c}$ & $2.00 \mathrm{a}$ & $1.74 \mathrm{~b}$ & $26.42 d$ & 8.30 & $133.75 \mathrm{a}$ & $179.58 \mathrm{a}$ & $313.33 \mathrm{a}$ & $42.51 \mathrm{~b}$ \\
\hline 30 & $40.46 b$ & 12.99 & $2.16 \mathrm{~b}$ & $16.67 \mathrm{bc}$ & $1.29 \mathrm{~b}$ & $1.73 b$ & $28.87 \mathrm{c}$ & 8.35 & $119.02 b$ & $137.08 b$ & $256.10 \mathrm{~b}$ & $45.82 \mathrm{a}$ \\
\hline 40 & $38.61 b c$ & 13.12 & $2.21 \mathrm{ab}$ & $19.86 \mathrm{a}$ & $1.31 \mathrm{~b}$ & $1.93 \mathrm{a}$ & $38.20 \mathrm{a}$ & 8.40 & $117.37 \mathrm{~b}$ & $129.58 \mathrm{c}$ & $246.96 b$ & $46.34 \mathrm{a}$ \\
\hline 50 & $37.61 \mathrm{c}$ & 12.99 & $2.51 \mathrm{a}$ & $17.39 \mathrm{~b}$ & $1.20 \mathrm{~b}$ & $1.89 \mathrm{a}$ & $32.83 b$ & 8.46 & $105.33 \mathrm{c}$ & $118.40 \mathrm{~d}$ & $223.73 c$ & $46.10 \mathrm{a}$ \\
\hline $\mathrm{CV}(\%)$ & 5.14 & 5.74 & 1.19 & 8.34 & 10.68 & 6.94 & 3.03 & 1.19 & 3.34 & 4.39 & 3.27 & 2.00 \\
\hline \multicolumn{13}{|l|}{ Cultivar } \\
\hline G-2 & $37.47 \mathrm{c}$ & $11.59 \mathrm{~b}$ & $1.80 \mathrm{c}$ & $13.08 \mathrm{c}$ & $0.83 c$ & 1.80 & $23.33 \mathrm{c}$ & $5.42 \mathrm{c}$ & $70.75 c$ & $104.64 c$ & $175.39 \mathrm{c}$ & $40.28 b$ \\
\hline BS-5 & $42.96 a$ & $13.79 \mathrm{a}$ & $2.80 \mathrm{a}$ & $20.44 a$ & $1.82 \mathrm{a}$ & 1.84 & $37.79 \mathrm{a}$ & $10.11 \mathrm{a}$ & $151.24 \mathrm{a}$ & $169.23 \mathrm{a}$ & $320.46 a$ & $47.72 \mathrm{a}$ \\
\hline PB-1 & $39.89 b$ & $13.42 \mathrm{a}$ & $2.08 \mathrm{~b}$ & $18.34 \mathrm{~b}$ & $1.71 \mathrm{~b}$ & 1.83 & $33.62 \mathrm{~b}$ & $9.50 \mathrm{~b}$ & $134.62 b$ & $149.63 b$ & $284.24 b$ & $47.57 \mathrm{a}$ \\
\hline $\mathrm{CV}(\%)$ & 5.24 & 4.36 & 8.55 & 5.80 & 6.94 & 6.19 & 4.04 & 1.01 & 3.26 & 3.90 & 2.46 & 2.76 \\
\hline $\mathrm{SE}( \pm)$ & 0.7361 & 0.0529 & 0.0060 & 0.1675 & 0.0017 & 0.0021 & 0.2713 & 0.0012 & 2.503 & 5.052 & 6.819 & 0.259 \\
\hline
\end{tabular}

Figures having similar letter (s) do not differ significantly at $5 \%$ level as per DMRT

Table 3. Interaction effect of cultivar and row spacing on growth, yield attributes and yield of soybean in Kharif-II season

\begin{tabular}{|c|c|c|c|c|c|c|c|c|c|c|c|c|c|}
\hline Cultivar & $\begin{array}{l}\times \text { Row } \\
\text { spacing } \\
(\mathrm{cm})\end{array}$ & $\begin{array}{l}\text { Plant } \\
\text { height } \\
(\mathrm{cm})\end{array}$ & $\begin{array}{l}\text { Nodes } \\
\text { plant }^{-1} \\
\text { (no.) }\end{array}$ & $\begin{array}{l}\text { Branches } \\
\text { plant }^{-1} \\
\text { (no.) }\end{array}$ & $\begin{array}{l}\text { Fertile pods } \\
\text { plant }^{-1} \\
\text { (no.) }\end{array}$ & $\begin{array}{l}\text { Non fertile } \\
\text { pods plant } \\
\text { (no.) }\end{array}$ & $\begin{array}{l}\text { Seeds } \\
\text { pod }^{-1} \\
\text { (no.) }\end{array}$ & $\begin{array}{l}\text { Seed } \\
\text { plant }^{-1} \\
\text { (no.) } \\
\end{array}$ & $\begin{array}{l}\text { Weight } \\
\text { of } 100 \\
\text { seeds }(\mathrm{g})\end{array}$ & $\begin{array}{l}\text { Seed yield } \\
\left(\mathrm{g} \mathrm{m}^{-2}\right)\end{array}$ & $\begin{array}{l}\begin{array}{l}\text { Stover } \\
\text { yield } \\
\left(\mathrm{g} \mathrm{m}^{-2}\right)\end{array} \\
\end{array}$ & $\begin{array}{l}\text { Total dry } \\
\text { mater } \\
\left(\mathrm{g} \mathrm{m}^{-2}\right)\end{array}$ & $\begin{array}{l}\text { Harvest } \\
\text { index } \\
(\%)\end{array}$ \\
\hline \multirow[t]{4}{*}{ G-2 } & 20 & 40.57 & 10.97 & 1.60 & $11.27 \mathrm{j}$ & $1.37 \mathrm{e}$ & 1.79 & $20.00 \mathrm{i}$ & 5.28 & $77.94 f$ & $111.25 \mathrm{f}$ & $189.19 \mathrm{~g}$ & $41.22 \mathrm{e}$ \\
\hline & 30 & 39.50 & 12.20 & 1.80 & $15.10 \mathrm{gh}$ & $0.83 \mathrm{f}$ & 1.59 & $24.00 \mathrm{~h}$ & 5.35 & $77.51 \mathrm{f}$ & $108.75 f$ & $186.26 \mathrm{c}$ & $41.62 \mathrm{e}$ \\
\hline & 40 & 35.43 & 12.03 & 1.77 & $12.43 \mathrm{ij}$ & $0.53 \mathrm{~g}$ & 1.96 & $24.30 \mathrm{~h}$ & 5.44 & $65.15 \mathrm{~g}$ & $103.75 \mathrm{gh}$ & 168.90h & $38.57 f$ \\
\hline & 50 & 34.17 & 11.17 & 2.03 & 13.50hi & $0.57 \mathrm{~g}$ & 1.86 & $25.03 \mathrm{~h}$ & 5.61 & $62.40 \mathrm{~g}$ & $94.80 \mathrm{~g}$ & $157.20 \mathrm{i}$ & 39.73ef \\
\hline \multirow[t]{3}{*}{ BS-5 } & 20 & 46.30 & 13.70 & 2.63 & $17.73 \mathrm{def}$ & $2.57 \mathrm{a}$ & 1.72 & $30.50 \mathrm{fg}$ & 10.11 & $166.57 \mathrm{a}$ & $233.75 \mathrm{a}$ & $400.32 \mathrm{a}$ & $41.61 \mathrm{e}$ \\
\hline & 30 & 43.13 & 13.70 & 2.83 & $18.70 \mathrm{bcd}$ & $1.60 \mathrm{~d}$ & 1.74 & $32.53 \mathrm{ef}$ & 10.14 & $154.73 b c$ & $157.50 \mathrm{c}$ & $312.23 \mathrm{c}$ & $49.57 \mathrm{ab}$ \\
\hline & 50 & 40.60 & 14.03 & 2.87 & $18.17 \mathrm{cde}$ & $1.50 \mathrm{dc}$ & 1.95 & $35.40 \mathrm{~cd}$ & 10.10 & $135.42 \mathrm{~d}$ & $134.40 \mathrm{e}$ & $269.82 \mathrm{e}$ & $50.19 \mathrm{ab}$ \\
\hline \multirow[t]{6}{*}{ PB-1 } & 20 & 44.37 & 13.23 & 1.87 & $16.70 \mathrm{efg}$ & $2.07 \mathrm{~b}$ & 1.72 & $28.77 \mathrm{~g}$ & 9.51 & $156.74 b$ & $193.75 b$ & $350.59 b$ & $44.72 d$ \\
\hline & 30 & 38.53 & 13.07 & 1.83 & $16.20 \mathrm{fg}$ & $1.43 \mathrm{de}$ & 1.86 & $30.07 \mathrm{de}$ & 9.56 & $124.83 \mathrm{e}$ & $145.00 \mathrm{~d}$ & $269.83 \mathrm{e}$ & $46.26 \mathrm{~cd}$ \\
\hline & 40 & 38.60 & 13.60 & 2.00 & $19.97 b c$ & $1.80 \mathrm{c}$ & 1.89 & $37.57 b c$ & 9.65 & $138.73 d$ & $133.75 \mathrm{e}$ & $272.48 \mathrm{e}$ & $50.92 \mathrm{a}$ \\
\hline & 50 & 38.07 & 13.77 & 2.63 & $20.50 \mathrm{~b}$ & $1.53 \mathrm{de}$ & 1.86 & $38.07 \mathrm{~b}$ & 9.67 & $118.18 \mathrm{e}$ & $126.00 \mathrm{e}$ & $244.18 \mathrm{f}$ & $48.39 b c$ \\
\hline & $\mathrm{CV}(\%)$ & 5.24 & 4.36 & 8.55 & 5.80 & 4.04 & 6.19 & 4.04 & 1.01 & 3.26 & 3.90 & 2.46 & 2.76 \\
\hline & $\mathrm{SE}( \pm)$ & 2.924 & 0.212 & 0.0242 & 0.6701 & 0.0023 & 0.009 & 1.0852 & 0.0048 & 10.0113 & 20.206 & 27.281 & 1.0372 \\
\hline
\end{tabular}

Figures having similar letter (s) do not differ significantly at 5\% level as per DMRT 


\section{Conclusions}

It may be concluded that soybean cultivar BARI soybean -5 (BS-5) could be sown at $20 \mathrm{~cm}$ apart rows to obtain higher yield in kharif II season.

\section{References}

Ball, R. A., Purcell, L. C. and Vories, E. D. 2000. Optimizing soybean plant population for a short season production system in the Southern USA. Crop Science. 40 : 757-764.

BARI, 2005. Krishi Prozukti Haat Boi (Handbook of Agrotechnology). Bangladesh Agricultural Research Institute, Joydebpur, Gazipur. 155-160 pp.

Gardner, F. P., Pearce, R. B. and Mitchell, R. L. 1985. Physiology of Crop Plants. Iowa State University Press, pp. 1-327.

Pendersen, P. and Lauer, J. G. 2003. Corn and soybean response to rotation sequence, row spacing and tillage system. Agronomy Journal, 95 : 965-997.
Rahman, M. M. and Hanif, M. A. 2006. Effect of row spacing and phosphorus level on soybean seed yield and quality. Bangladesh Journal of Seed Science and Technology, 11(1\&2) : 69-75.

Rahman, M. M. and Islam, M. A. 2006. Effects of sowing date on seed yield and yield attributes of soybean. Journal of the Bangladesh Agricultural University, 4(1) : 23-31.

Rahman, M. M., Hampton, J. G. and Hill, M. J. 2005. Growth response of cool tolerant soybean to variation in sowing date. Agronomy New Zealand, 35 : 81-96.

Rahman, M. M., Mwakangwale, M. G., Hampton, J. G. and Hill, M. J. 2004. The effect of plant density on seed yield of two cool tolerant soybean cultivars in Canterbury. Agronomy New Zealand, 34 : 149-159.

Rahman, M., Hossain, M. and Bell, R. W. 2011. Plant density effects on growth, yield and yield components of two soybean varieties under equidistant planting arrangement. Asian Journal of Plant Sciences, 10(5): 278-286. 